\title{
Multicultural Education of Autochthons and Migrants in Russia
}

\author{
Endzhe Latypova ${ }^{1}$ \\ Kazan Federal University, Kazan, Russia \\ Vladimir Kozmenko \\ Peoples Friendship University of Russia (RUDN University), Moscow, Russia \\ Saken Toktamysov \\ Peoples Friendship University of Russia (RUDN University), Moscow, Russia
}

\begin{abstract}
The study aims to analyze modern scientific approaches to multicultural education of autochthons, migrants, and foreign students to assess the real state and prospects of such education development in Russia. The 2019 RPORC (Russian Public Opinion Research Center) survey "Higher education: in Russia or abroad?" was used in the study. A total of 1,600 respondents took part in the study. Based on the Pareto Optimality principle, a model of an integrated multicultural education process has been developed. Survey data analysis has shown that for the majority of Russians $(78 \%)$ it is not important whether their children/grandchildren will receive higher education abroad. Russian society has a tolerant attitude towards domestic and world educational systems. The practical application of the research results is possible with the improvement of training programs, the exchange of international experience and further research into the problems of multicultural education development.
\end{abstract}

Keywords: adaptation, ethnocultural diversity, multicultural learning, multiculturalism, process.

Today, an integral feature of the modern world is the multicultural environment of human life and activity (Latypova, 2016; Yusupova \& Markova, 2015). One of the peculiarities is the integration of various ethnocultural groups into a single multicultural society based on the principles of mutual respect and justice (Napier, 2014). Multicultural education has evolved from ethnic studies to multicultural education in a global context (Banks, 2013). Ethnicity is mainly related to culture, shared meaning, but it is also rooted in social interaction. Multicultural education is a form of implementing a national education. The aim of multicultural education is to create equal conditions for all students regardless of race, gender, culture, language, religion, and social class (Dameron et al., 2020; Mostafazadeh et al., 2015). The multicultural education process is a set of socially determined sequential actions, which are based on the ideas of equality and mutual respect, aimed at educating a person who perceives cultural diversity and the values of a multicultural society. The main principle of the multicultural education process is based on maintaining the dialogue of cultures, tolerance and humanism (Cherng \& Davis, 2019; Shannon-Baker, 2018). Multiculturalism is a concept that tries to change society in such a way as to integrate differences into one whole (Napier, 2014). Multicultural education defines a set of principles, values and practices based on the ideas of multiculturalism that can be embodied in any professional activity fields (Arsal, 2019). In multiculturalism, moral ideals include knowledge about and acceptance of minorities and

\footnotetext{
${ }^{1}$ Correspondent Author E-Mail: latypovaend@rambler.ru
} 
equitable treatment. Immoral tenets include prejudice, bullying and violence, separation, injustice, abuse, neglect, and exclusion. Groups and individuals should be examined to reveal immoral beliefs and practices, so that one can use the information to right the wrongs (Beckett \& Kobayashi, 2020; Erbas, 2019; Wilder et al., 2017). At the same time, multiculturalism brings diversity to the way of life through the discovery of new cultures and, in particular, encourages people to think more about their own culture (Medkova, 2015). With the growing influence of internationalization and globalization, significant changes have taken place in education. The following factors should be taken into account:

- the views of each country on multicultural education;

- the competence that students demonstrate in a multicultural context;

- the need to preserve and support local cultural practices that already exist in the national education system;

- the role of comparative research in the development of multicultural education (Aniskin et al., 2015).

\section{Literature Review}

In the scientific discourse, this problem was considered for the first time from the point of view of the relationship between autochthons, migrants, and foreign students. Autochthons mean the indigenous people of a certain region (Anikin, 2007). The substantiation of this problem's essence and possible ways to solve it, which contribute to the formation of mutual understanding, is new for research. Recently, there has been an increase in interest in the problems of multiculturalism in education (Dzhurinskiy, 2016; Nayar \& Wright St.Clair, 2020). Educational institutions around the world are faced with migration problems, as well as existing racial and ethnic diversity (Sleeter, 2018). Taiwan, for example, is interested in multicultural education to recognize differences and reduce prejudice. In such cases, multicultural education is less about challenging who has the power to define issues and solutions and more about managing an influx of diversity (Liu \& Lin, 2011). Multicultural education has changed immensely US schools and society. For example, the US population has changed considerably from once European American to multi-ethnic, multiracial, and multicultural (Nieto, 2017). In the US, research on the academic and social impact of ethnic studies pays particular attention to academic results. Many minorities want their youth not only to be proud of their cultural and linguistic backgrounds but also to function well in their cultural communities (Sleeter, 2018). UNESCO explains that multicultural education focuses on other cultures to produce acceptance or at least tolerance of these cultures. Intercultural education aims to go beyond passive coexistence and to achieve a sustainable way of living together in multicultural societies through the creation of an understanding of, respect for, and dialogue between the different cultural groups (UNESCO, 2006).

An important goal of multicultural education is to help educators minimize the challenges of diversity and maximize its educational opportunities (Toktamysov et al., 2019). They also need to explore and clarify their racial and ethnic attitudes, develop pedagogical knowledge and skills necessary to work effectively with students from a variety of racial, ethnic, cultural, gender, social, and religious backgrounds (Banks, 2017). Three specific forms of development of multicultural pedagogy are considered in the literature: conservative, liberal and critical (Alismail, 2016). Three key areas of multicultural education have developed in world science: critical, pluralistic, and cultural assimilation. There is also a separate approach based on human self-determination in the generally accepted spiritual values of national culture (Zilliacus et al., 2017). 
It is necessary to preserve the best directions of the domestic education system in the context of adaptation to the globalization trends in education (Gukalenko \& Borisenkov, 2016). The migration growth of people with different cultures and mentality is rapidly changing the modern world. This necessitates the study of these complex processes, which will further contribute to the development of domestic multicultural education and provide an opportunity to exchange the experience with scientists from other countries. An effective solution to many problems of multicultural education requires studying this phenomenon, taking into account the analysis of international experience and specifics of a domestic education system. The importance of multicultural education development in modern Russia, where more than 130 ethnic groups live, is determined by the progressive trend of ethnic division, intolerance and intransigence, which manifests itself in the behavior of individuals (ethnic prejudices, avoiding interethnic contacts and conflicts) and collective actions (ethnic aggression, national discrimination, ethnic conflicts). Based on the relevance of the issue, the study aims to analyze modern scientific approaches to intercultural education of autochthons, migrants, and foreign students, as well as to assess the real state and prospects of ensuring the development of multicultural higher education in Russia.

The study solves a number of scientific problems:

- researching the essence of multicultural education in the world and domestic scientific discourse and determining its significance for overcoming obstacles in obtaining equal access to education, regardless of existing racial, ethnic, cultural, and other differences;

- analyzing the interaction of three subgroups (autochthons, migrants, and foreign students) in the multicultural education process;

- substantiating the model of integrated multicultural education.

\section{Materials and Methods}

\section{Research design}

This work examines an integrated multicultural education process based on an extensive theoretical base in the field of multicultural education, as well as numerous publications.

The study used a survey and built a model of an integrated multicultural education process. When building the model, the idea of Banks (2017) was considered. According to this idea, the aim of multicultural education is to help educators minimize the problems associated with diversity and maximize educational opportunities. For this model, the Pareto Optimality implies that meeting students' educational needs reaches a maximum, and multicultural skills development becomes optimal in the following conditions. Namely, if any change in these actions helps to minimize multicultural education problems or maximize multicultural education opportunities, while not impairing the interests of other participants in society (Marshall, 2007).

The authors used the data of the 2019 RPORC survey "Higher education: in Russia or abroad?" that was conducted in September 2019. The choice of this survey for the study was due to the need to study the perception of multiculturalism ideas among different age groups of the Russian Federation. Questions were prepared by RPORC. Three questions were asked:

- "In general, how would you rate the quality of higher education in Russia?";

- "If comparing higher education in Russia and abroad, is the higher education abroad better, worse, or the same as in Russia?";

- "Is it rather important or rather unimportant for you that your children/grandchildren get higher education abroad?" 
A qualitative survey data analysis and the interpretation of the answers were made.

\section{Intervention}

The survey took into account the opinion of citizens of the Russian Federation in the age category of 18 years and older. The respondents were divided into several age groups: 18$24 ; 25-34 ; 35-44 ; 45-59 ; 60$ and over. The telephone survey method was used with a special stratified two-base random sample of mobile and landline telephone numbers. A total of 1,600 respondents took part in the study. The error rate is almost 3\%. Demographic information was obtained during the survey. Sample of respondents was built on the basis of a complete list of telephone numbers used in the territory of the Russian Federation.

\section{Research Limitations}

The study examined (through a telephone survey) the opinions of the Russian Federation citizens on the development of Russian and foreign higher education. The level of multicultural education development in higher educational institutions and scientific organizations in Russia in 2018/19 was considered by analyzing the number of foreign students (incl. migrants), as well as determining their share in the overall structure of students. Gender differences were not taken into account. The authors used the data of the 2019 RPORC survey "Higher education: in Russia or abroad?"

\section{Statistical Analysis}

The survey statistics were tested for the probability of selection and for sociodemographic parameters. For this sample, the maximum error size with a $95 \%$ probability does not exceed $2.5 \%$. In addition to sampling error, survey data can be biased by the wording of the questions and various other circumstances. Excel software was used to analyze and process survey data.

The logical framework for data research included the analysis of statistical information on migrants, followed by an analysis of information on students. The proportion of foreign students in relation to all migrants, as well as in relation to students-autochthons, was analyzed. Research into the problems of multiculturalism and multicultural education touches upon many ethical issues that relate to the terminology used, the individual views on the studied phenomena and processes in modern society. Taking into account all the above, the basic ethical principles of an objective and impartial approach to the study were agreed at the beginning of its implementation.

\section{Results}

The study is based on the desire to understand the problem of multicultural education of autochthons, migrants, and foreign students in Russia. Firstly, these are autochthons or local population, which may initially have stereotypes about other subgroups, or adhere to a stable opinion and tolerant approach to national, ethnic, or religious differences. The second subgroup is usually made up of migrants who have arrived in the country for work, education, or other purposes. The third subgroup includes foreign citizens who study in Russia (Figure 1).

At the same time, it is necessary to understand that the goals of migrants and foreign students who participate in a multicultural education process may coincide on some issues, while differ on others. The coincidence refers to the understanding of the need for higher education as the basis for further improvement of material well-being and self-realization, while the difference concerns the desire to stay in Russia, obtaining a residence permit and citizenship. 
Foreign students, as a rule, after receiving a diploma, return to their homeland, while migrants remain and seek to obtain the right to live and socialize in society.

\section{Figure 1}

The Relationship Between the Main Subgroups - Participants in the Multicultural Education Process

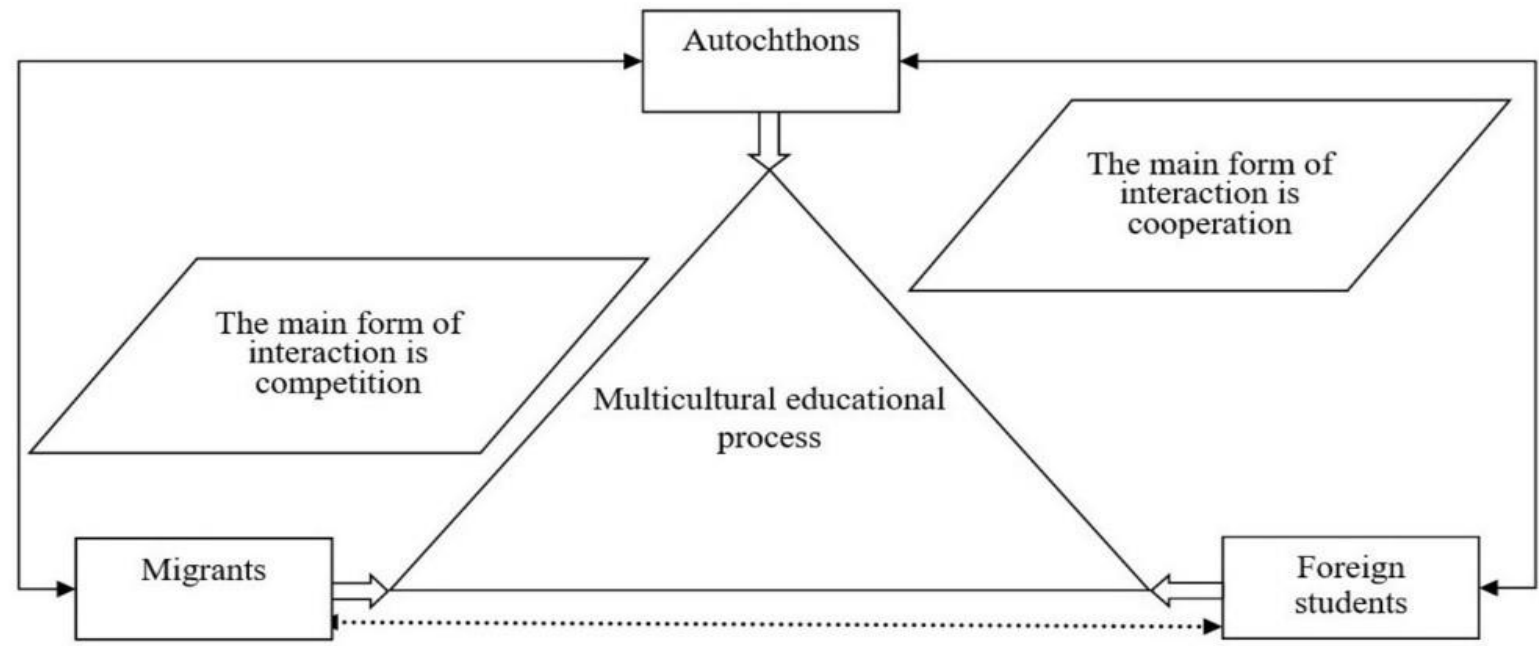

Source: The authors' development

For a better understanding of the issue under study, an in-depth analysis of migration statistics and its structure, as well as the total number of students in Russia and the share of foreign students, was carried out. In recent years, the flow of migration to Russia has been increasing annually, as evidenced by government statistics. If in 2000, migration to the Russian Federation amounted to 359.3 thousand people, then in 2018 there was a significant increase to 565.7 thousand people, and in 2019 - to 701.2 thousand people. At the same time, the main flow is made up of migrants from the Commonwealth of Independent States (CIS) (Figure 2).

\section{Figure 2}

Dynamics of International Migration to the Russian Federation

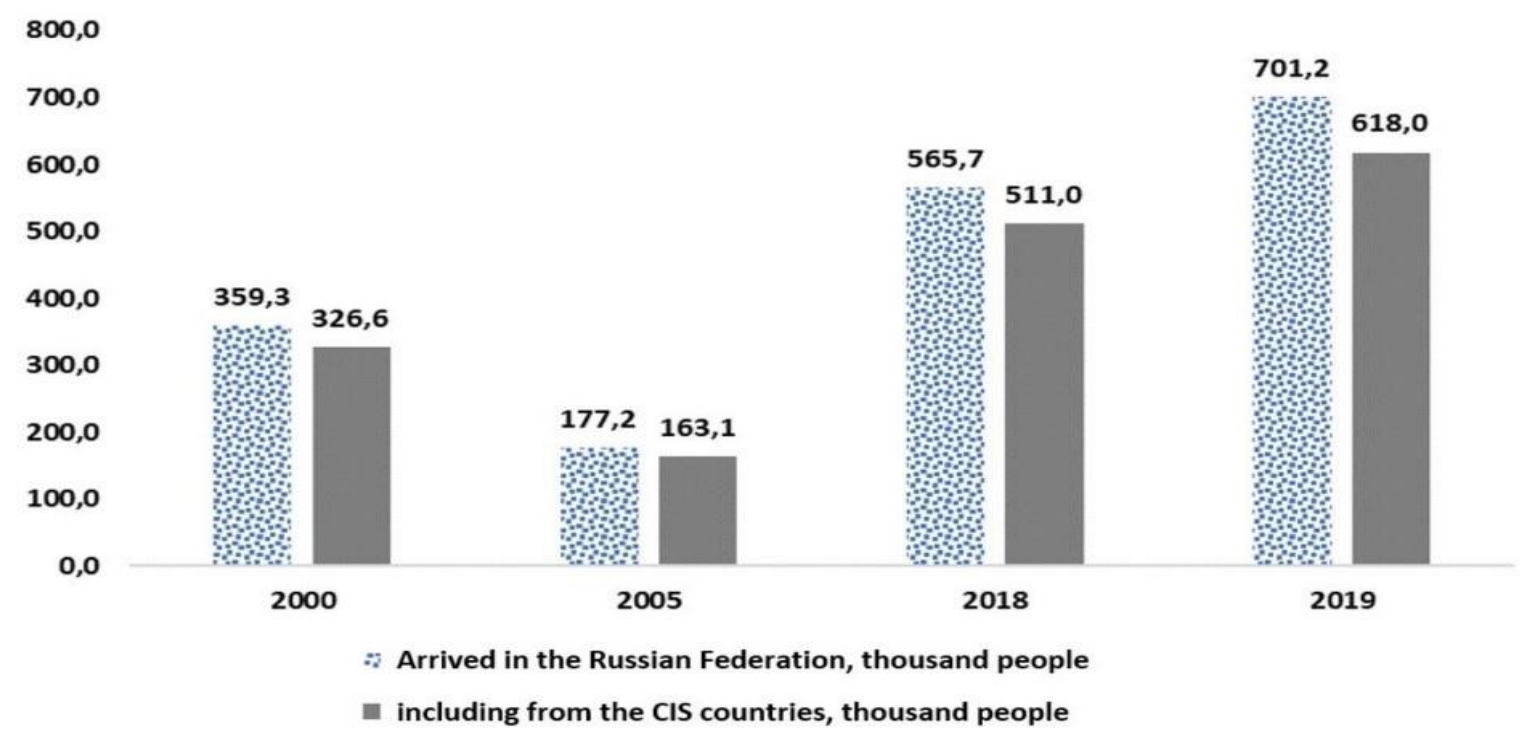

Source: Compiled on the basis of data from the Federal State Statistics Service of the Russian Federation (n.d.) 
A significant increase in migration in recent years has raised a discourse in society regarding the need for a new multicultural policy, where great importance should be given to the education and adaptation of migrants to the domestic culture and language, while preserving the right to one's own identity and respect from the autochthons. Education is the area where the development of multiculturalism ideas is most effectively promoted and there is an opportunity to find the most optimal model of interaction between autochthons, migrants, and foreign students.

It is generally accepted that the main flow of migrants is formed by labor migrants. However, in recent years, the flow of migrants who seek to obtain higher education in Russia has also increased (Table 1).

\section{Table 1}

The Number of Students Enrolled in Undergraduate and Graduate Programs in the Russian Federation (At the Beginning of the Academic Year, Thousand People)

\begin{tabular}{lccc} 
Year & All students & including foreign students & $\begin{array}{c}\text { Share of foreign students, } \\
\%\end{array}$ \\
\hline $2000 / 2001$ & 4741.4 & 59.0 & 1.2 \\
$2005 / 2006$ & 7064.6 & 78.1 & 1.1 \\
$2018 / 2019$ & 4161.7 & 247.7 & 6.0 \\
$2019 / 2020$ & 4068.3 & 267.1 & 6.6 \\
\hline
\end{tabular}

Source: Compiled on the basis of data from the Federal State Statistics Service of the Russian Federation (n.d.)

If in the 2000/2001 academic year the number of foreign students enrolled in undergraduate and graduate programs was 59 thousand people or $1.2 \%$, then already in $2018 / 2019$ it amounted to 247.7 thousand people (6\%), and in 2019/2020 - 267.1 thousand people $(6.6 \%)$. A comparative study of this phenomenon by analyzing data from the Federal Service of State Statistics of the Ministry of Science and Higher Education of the Russian Federation revealed that 701,234 migrants arrived in the country in 2019, of which 57,371 were accepted for training as foreign students, the proportion of which was $8.2 \%$ of the total number of arrived. At the same time, 735,094 students were accepted for training, including 57,371 citizens of 238 foreign states and territories, or almost $7.8 \%$ of the total. The largest number of foreign students was accepted for training from the Republic of Kazakhstan - 13622, the Republic of Uzbekistan - 10511, Turkmenistan - 10274 (Figure 3).

When studying the structure of migrants in more depth and comparing it with the structure of foreign students admitted to study in 2019, one can see some differences. The largest share of foreign students arrived from:

- Turkmenistan - 70.2\%;

- China-33.5\%;

- Republic of Uzbekistan - 17.3\%;

- Republic of Kazakhstan - 15.8\%;

- Republic of Belarus - $12.2 \%$.

On the other hand, the smallest share was observed for Ukraine - 1.4\%, Kyrgyz Republic - 3.1\%, Azerbaijan - 4.4\%, and Tajikistan - $4.5 \%$. 


\section{Figure 3}

Quantitative Analysis of Migrants and Foreign Students Accepted for Training in Higher Educational Institutions and Scientific Organizations of the Russian Federation in 2019

The ratio of foreign students admitted to study on a general admission basis and arrived migrants, persons (\%)

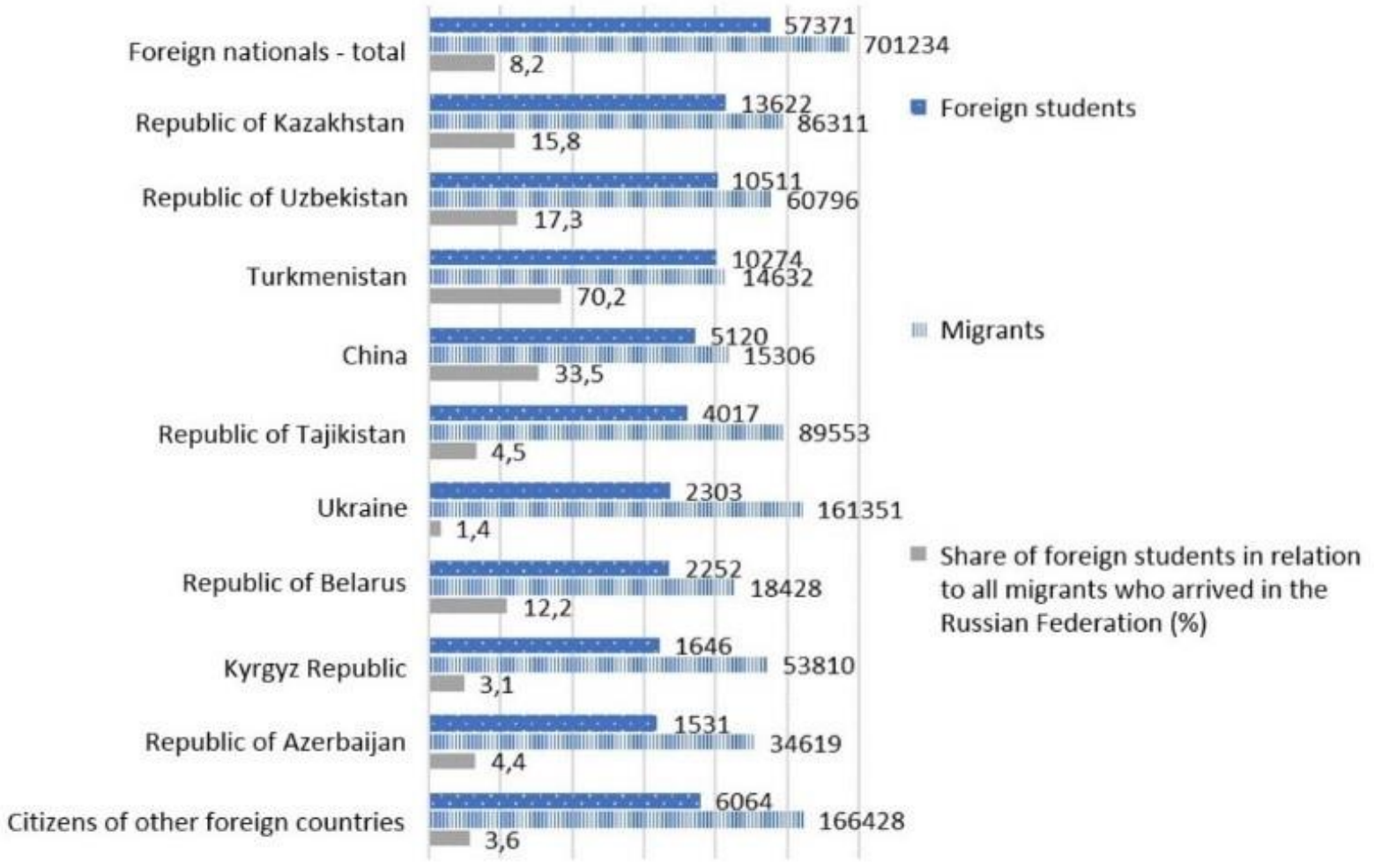

Source: Compiled on the basis of data from the Federal State Statistics Service of the Russian Federation (n.d.)

Below are the survey data on how respondents assess Russian education (Table 2). Among all the respondents, 22\% gave high marks, and 29\% - low. It should be noted that the quality of higher education in Russia is highly rated by 18 -24-year-old respondents (33\%), while older people gave low marks (45-59-year-olds - $29 \%$ and $60+$ year-olds - 31\%). In general, respondents consider higher education in Russia to be of average quality (39\%).

\section{Table 2}

Results of Assessing the Quality of Higher Education in Russia (Closed-Ended Question, One Answer, \% of All Respondents)

\begin{tabular}{lllllll}
\hline & $\begin{array}{l}\text { All } \\
\text { respondents }\end{array}$ & $\begin{array}{l}18-24 \\
\text { years } \\
\text { old }\end{array}$ & $\begin{array}{l}25-34 \\
\text { years } \\
\text { old }\end{array}$ & $\begin{array}{l}35-44 \\
\text { years } \\
\text { old }\end{array}$ & $\begin{array}{l}45-59 \\
\text { years } \\
\text { old }\end{array}$ & $\begin{array}{l}60 \text { years } \\
\text { and } \\
\text { older }\end{array}$ \\
\hline Very low & 9 & 11 & 6 & 5 & 10 & 10 \\
Rather low & 20 & 16 & 21 & 20 & 19 & 21 \\
Average & 39 & 32 & 44 & 38 & 35 & 41 \\
$\begin{array}{l}\text { Rather high } \\
\text { Very high }\end{array}$ & 19 & 29 & 18 & 23 & 18 & 13 \\
$\begin{array}{l}\text { I find it difficult to } \\
\text { answer }\end{array}$ & 3 & 4 & 4 & 5 & 2 & 1 \\
\hline
\end{tabular}

Source: developed by the authors based on Initiative of All-Russian Public Opinion Research Center (2019) 
Another noteworthy aspect of the issue under study is the attitude of Russian citizens to the education of their children/grandchildren abroad. This survey made it possible to indirectly reveal the perception of multicultural education in Russian society and tolerance to another educational culture. The analysis of the survey showed that for the majority of Russians it is not important whether their children/grandchildren receive higher education abroad $-78 \%$. This is most important for young people (18-24 years old (31\%)) and least of all for the category $60+(14 \%)$. The opposite situation is for the answer "Rather not important": the age group 1824 has the lowest indicator of $65 \%$, and the category $60+$ has the highest $(83 \%)$.

Here it can be concluded that Russian society has a more tolerant attitude towards domestic and world educational systems (Table 3).

\section{Table 3}

"Is it Rather Important or Rather Unimportant for You That Your Children/Grandchildren Get Higher Education Abroad?" (Closed-Ended Question, One Answer Received, \% of All Respondents)

\begin{tabular}{lllllll}
\hline & $\begin{array}{l}\text { All } \\
\text { respondents }\end{array}$ & $\begin{array}{l}18-24 \\
\text { years } \\
\text { old }\end{array}$ & $\begin{array}{l}25-34 \\
\text { years } \\
\text { old }\end{array}$ & $\begin{array}{l}35-44 \\
\text { years } \\
\text { old }\end{array}$ & $\begin{array}{l}45-59 \\
\text { years } \\
\text { old }\end{array}$ & $\begin{array}{l}\text { 60 years } \\
\text { and } \\
\text { older }\end{array}$ \\
\hline Rather important & 19 & 31 & 28 & 19 & 15 & 14 \\
Rather not important & 78 & 65 & 70 & 77 & 83 & 83 \\
I am at a loss to answer & 3 & 4 & 3 & 4 & 3 & 3 \\
\hline
\end{tabular}

Source: Developed by the authors based on Initiative of All-Russian Public Opinion Research Center (2019)

Table 4 examines the qualitative aspect of the educational issue. It can be assumed that at the subconscious level of the respondents, when choosing their answer, many aspects were taken into account, including the level of tolerant attitude towards other nationalities and their perception of other cultures. Some respondents $(26 \%)$ believe that higher education in Russia is the same as abroad. A third part (mainly young people aged 18-24 (52\%)) is confident that education abroad is better (27\%). At the same time, a significant part of the respondents found it difficult to compare higher education in Russia and abroad (36\%).

\section{Table 4}

If Comparing Higher Education in Russia and Abroad, is The Higher Education Abroad Better, Worse, or the Same As in Russia? (Closed-Ended Question, One Answer Received, \% of All Respondents)

\begin{tabular}{|c|c|c|c|c|c|c|}
\hline & $\begin{array}{l}\text { All } \\
\text { respondents }\end{array}$ & $\begin{array}{l}18-24 \\
\text { years } \\
\text { old }\end{array}$ & $\begin{array}{l}25-34 \\
\text { years } \\
\text { old }\end{array}$ & $\begin{array}{l}35-44 \\
\text { years } \\
\text { old }\end{array}$ & $\begin{array}{l}45-59 \\
\text { years } \\
\text { old }\end{array}$ & $\begin{array}{l}60 \text { years } \\
\text { and } \\
\text { older }\end{array}$ \\
\hline Rather better & 27 & 52 & 38 & 24 & 19 & 22 \\
\hline Rather worse & 11 & 8 & 8 & 13 & 12 & 10 \\
\hline Rather the same & 26 & 20 & 28 & 27 & 25 & 28 \\
\hline $\begin{array}{l}\text { I am at a loss to } \\
\text { answer }\end{array}$ & 36 & 20 & 25 & 36 & 44 & 40 \\
\hline
\end{tabular}

Source: Developed by the authors based on Initiative of All-Russian Public Opinion Research Center (2019)

The model of an integrated multicultural education process was built on the basis of Banks' idea (2017) (Figure 4). 


\section{Figure 4}

Model of An Integrated Multicultural Education Process

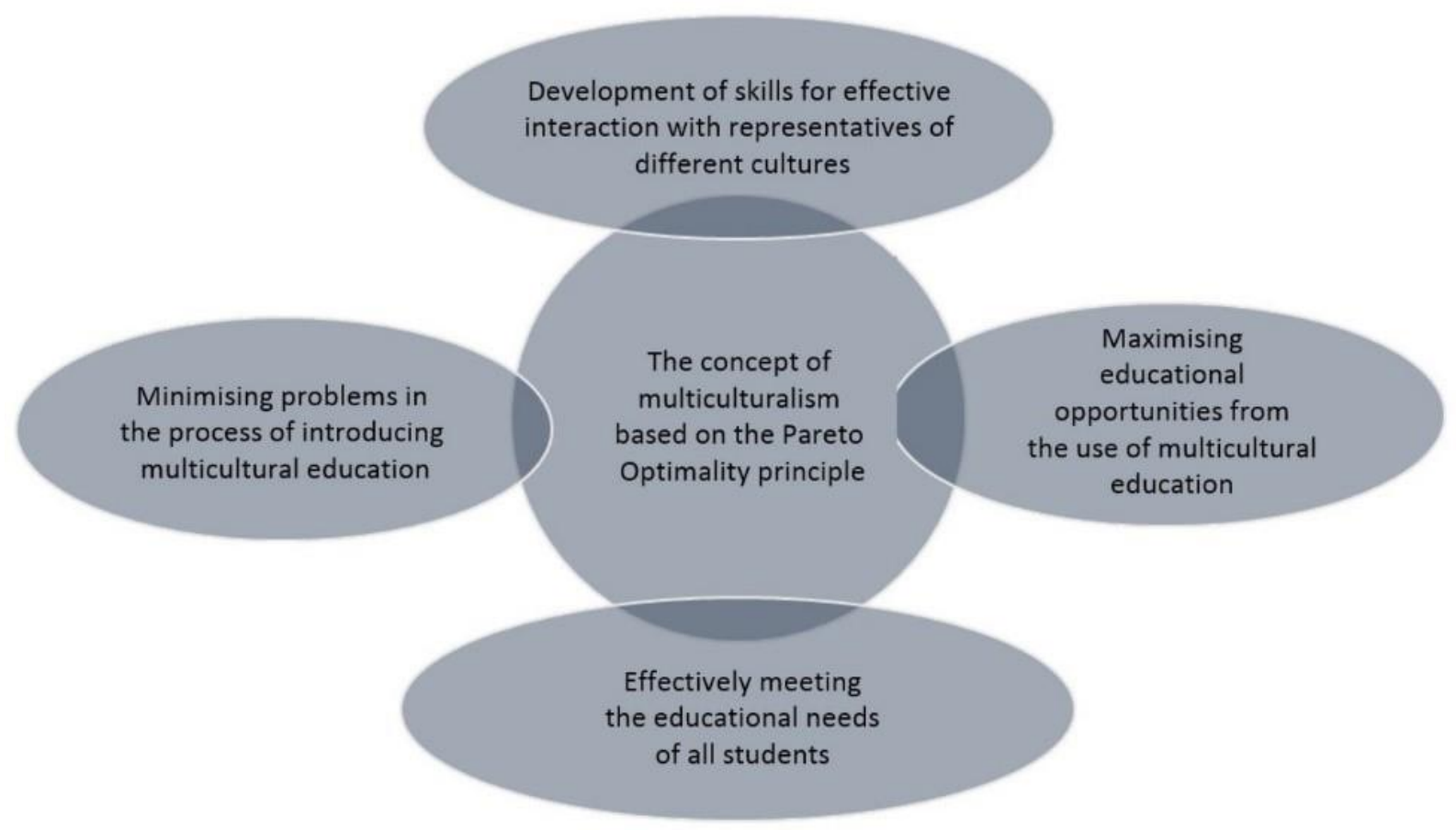

Source: The authors' development

Let us consider in more detail the proposed model of integrated multicultural education. A model of an integrated multicultural education process is based on 4 postulates:

- minimization of problems (minimization criteria are an increase in the total number of foreign students, a decrease in ethnocultural conflicts, an increase in the proportion of citizens who consider domestic education to be the best in comparison with a foreign one);

- maximizing educational opportunities (maximization criteria - an increase in the number of attracted talented youth from other countries to study in Russia);

- development of effective interaction skills (research data confirm the trend towards an increase in the number of foreign students in Russia);

- meeting the educational needs of all students, regardless of cultural, ethnic, racial, religious, and other differences (a significant number of students from the countries of Central Asia and the Caucasus, other ethno-religious groups study in Russia).

The main building blocks of this model are two cornerstone approaches in the multicultural learning environment. The first is to minimize the problems that may arise in the process of introducing multicultural education. These problems require separate consideration. For example, it is often possible to observe a superficial approach in multicultural practice of introducing students to music, literature, and language of migrants (Smolyaninova \& Trufanov, 2018).

The second approach involves maximizing multicultural education opportunities (Dolzhikova et al., 2016). The proposed model of an integrated multicultural education process can be implemented on the basis of previously adopted state educational standards (Federal State Educational Standards, 2016-2018). 


\section{Discussion}

According to the study purpose to analyze modern scientific approaches to the intercultural education of autochthons, migrants, and foreign students, one can make some assumptions. Autochthons have the most favorable educational opportunities and are least susceptible to problems of tolerant perception on the part of other students on cultural, ethnic, religious, and other differences in the process of multicultural education. Foreign students, as a rule, occupy an autonomous position in multicultural education, forming their own living ethnocultural space during the period of adaptation to new study conditions. Here, the main task of the host country is to create the necessary conditions for the full integration of foreign students into the local multicultural learning community based on equality and mutual respect for cultural, religious, and other differences. Students' exposure to the general educational culture of the host country as well as their adaptation and motivation to learn depend on it.

Migrants, unlike foreign students, are initially in the position of guests in their host country and cannot, to a large extent, claim the opportunity to take an autonomous position, which is necessary for the initial adaptation to new living conditions and changing the familiar environment, as well as the sphere of communication. However, it should be recognized that there are certain relationships between these three subgroups of the multicultural education process. These relationships relate to the general desire to achieve success by obtaining good grades and receiving recognition for academic achievement. Knowledge of the Russian language is also an important link for these three subgroups. It is important to understand when analyzing the data in Figure 2 that the existing multicultural education problems in Russia differ from those in other countries. In most cases, these migrants are well acquainted with the Russian language and culture and are easier to integrate into the Russian educational system and are less prone to conflict with the autochthonous population, who also study in these educational institutions.

Studying the answers received, it can be concluded that there is almost the same proportion of those respondents who consider that domestic higher education is better than a foreign one, and those who express the opposite opinion. It can be assumed that a majority of autochthons think that both foreign and domestic education provides equal opportunities, regardless of racial, ethnic, cultural, and other differences.

Unlike autochthons, who initially have more linguistic, civic, and other advantages from living in their own country, the effectiveness of multicultural education for migrants largely depends on their integration into the local society (Grebennikov et al., 2016). It also has some impact on the academic success of migrants. As a rule, migrants are very persistent and purposeful in achieving academic results in education and have much greater motivation for education compared to autochthons.

The conceptual outlines of the global perspective for the development of multicultural education are based on four significant interactive dimensions, namely: multicultural competence, fair pedagogy, curriculum reform, and social justice education (Ameny-Dixon, 2004). The development of pedagogy allows students to become citizens in a global and pluralistic society by developing educational programs aimed at meeting the needs of people who not only accept their own culture but also participate in the process of constructive dialogue with representatives of other cultures (Rasool \& Zhang, 2020; Sani, 2013).

National issues are relevant both in Russia and around the world, because there is a massive influx of migrants, which leads to a change in the ethnic composition and exacerbation of multicultural interaction problems (Sinyagin \& Rayfschnayder, 2016). In many European countries, the assimilation model initially prevailed, but gradually they began to abandon the assimilationist paradigm, moving to the policy of cultural pluralism, which later took shape as multiculturalism concept (Kalimullin et al., 2017). In the United States, where this concept first 
appeared, multicultural education developed within the framework of the intercultural movement (Kalimullin et al., 2017).

Multicultural education fosters understanding and support for new phenomena of cultural diversity, which can facilitate the educational impact of such experiential learning (Yun \& Zhang, 2017). When creating curricula for pedagogical students, it is necessary to justify ways to integrate diversity within programs, provide learning opportunities to help future educators apply innovative strategies, and link multicultural theory to practice in their own learning (Alismail, 2016; Toktamysov et al., 2021).

Multicultural education has evolved from ethnic studies to multi-ethnic education and multicultural education in a global context (Banks, 2013). Multicultural education in its current definition refers to the improvement of learning outcomes for students of all nationalities, social classes, religions, as well as gifted children (Mostafazadeh et al., 2015). Modernization of Russian education involves maintaining a single multicultural environment, overcoming ethnic tensions, social and cultural conflicts, and equality of national cultures (Yusupova \& Markova, 2015).

\section{Conclusions}

The survey data revealed a positive perception of multicultural education in Russian society and tolerance towards foreign educational culture. The survey analysis showed that for the majority of Russians it is not important whether their children/grandchildren receive higher education abroad - 78\%. Here it can be concluded that Russian society has a more tolerant attitude towards domestic and world educational systems. At the same time, the very idea of multicultural education is perceived positively, which is an important criterion for assessing the readiness to implement a model of integrated multicultural education.

The idea of multiculturalism has been actively developing for many years in many countries as an instrument of state policy aimed at supporting cultural diversity and overcoming stereotypes and prejudices based on ethnicity, nationality, gender, religious beliefs and other signs of identity. In general, when implementing multiculturalism ideas in different parts of the world, difficulties may arise due to lagging economic development, the presence of political and social instability, neighborhood with countries that are recipients of migrants and other reasons. In the educational sphere, the idea of multicultural education is aimed at adapting it to students of other nationalities and overcoming cultural, racial, and religious contradictions between them. It is possible to implement the proposed model of integrated multicultural education if there is an effective mechanism of state support for multicultural education development.

In general, when introducing multicultural education in Russia, a critical analysis of the existing world approaches to its development is necessary. Studying the conceptual foundations of multicultural education, one should pay close attention to the theoretical foundations and formulation of its main ideas in future research.

\section{Acknowledgments}

Endzhe Latypova has been supported by the Kazan Federal University Strategic Academic Leadership Program. Vladimir Kozmenko and Saken Toktamysov have been supported by the RUDN University Strategic Academic Leadership Program. 


\section{Disclosure Statement}

The authors declare that they have no conflict of interests to disclose.

\section{Data Availability Statement}

Data will be available on request.

\section{References}

Alismail, H. A. (2016). Multicultural education: Teachers' perceptions and preparation. Journal of Education \& Practice, 7(11), 139-146. https://doi.org/10.19030/tlc.v2i5.1825

All-Russian Public Opinion Research Center. (2019). All-Russian RPORC survey "Higher education: in Russia or abroad?" https://wciom.ru/index.php?id=236\&uid=9919.

Ameny-Dixon, G. M. (2004). Why multicultural education is more important in higher education now than ever: A global perspective. International Journal of Scholarly Academic Intellectual Diversity, 8(1), 1-9.

Anikin, A. E. (2007). Russian etymological dictionary. Vinogradov Russian Language Institute (RAS).

Aniskin, V. N., Bogoslovskiy, V. I., Dobudko, T. V., Zhukova, T. A., \& Pisareva, S. A. (2015). The prospects of multicultural education in Germany and Russia. Biomedical \& Pharmacology Journal, 8(2), 1033-1041. https://doi.org/10.13005/bpj/856

Arsal, Z. (2019). Critical multicultural education and preservice teachers' multicultural attitudes. Journal for Multicultural Education, 13(1), 106-118. https://doi.org/10.1108/JME-10-2017-0059

Banks, J. A. (2013). The construction and historical development of multicultural education, 1962-2012. Theory into Practice, 52(sup 1.1), 73-82. https://doi.org/10.1080/00405841.2013.795444

Banks, J. A. (2017). An introduction to multicultural education. Pearson Education.

Beckett, G. H., \& Kobayashi, M. (2020). A Meta-study of an Ethnographic Research in a Multicultural and Multilingual Community: Negotiations, Resources, and Dilemmas. American Journal of Qualitative Research, 4(1), 85-106. https://doi.org/10.29333/ajqr/8267

Cherng, H. Y. S., \& Davis, L. A. (2019). Multicultural matters: An investigation of key assumptions of multicultural education reform in teacher education. Journal of Teacher Education, 70(3), 219-236. https://doi.org/10.1177\%2F0022487117742884

Dameron, M. L., Camp, A., Friedmann, B., \& Parikh-Foxx, S. (2020). Multicultural education and perceived multicultural competency of school counselors. Journal of Multicultural Counseling \& Development, 48(3), 176-190. https://doi.org/10.1002/jmcd.12176

Dolzhikova, A. V., Moseikina, M. N., \& Vladimirsky, I. (2016). The educational policy strategy on foreign citizens coming to the Russian Federation, as a factor of their socio-cultural adaptation and integration. International Journal of Environmental \& Science Education, 11(9), 2619-2634. https://doi.org/10.12973/ijese.2016.711a

Dzhurinskiy, A. N. (2016). Multicultural education of autochthonous and immigrants: Ideas and practice. Human \& Education, 1(46), 51-58.

Erbas, Y. H. (2019). A qualitative case study of multicultural education in Turkey: Definitions of multiculturalism and multicultural education. International Journal of Progressive Education, 15(1), 23-43. https://doi.org/10.29329/ijpe.2019.184.2

Federal State Educational Standards. (n.d.). Official site. Retrieved from https://fgos.ru/.

Federal State Statistics Service of the Russian Federation. (n.d.). Official site. Retrieved from https://www.gks.ru/. 
Grebennikov, V. V., Bukalerova, L. A., Moseikina, M. N., Grudtsina, L. Y., \& Moiseyev, V. O. (2016). Educational migration of international students: Axiological aspect of the educational process. International Electronic Journal of Mathematics Education, 11(7), 2430-2441.

Gukalenko, O. V., \& Borisenkov, V. P. (2016). Multicultural education in the conditions of globalization. In SHS web of conferences (Vol. 29, p. 01026). EEIA. https://doi.org/10.1051/shsconf/20162901026

Kalimullin, A. M., Zakirova, V. G., \& Kamalova, L. A. (2017). Training of multicultural teachers in Europe, USA, Canada and Australia: Monograph. Part 2. Otechestvo Publishing.

Latypova, E. (2016). Studying the role of the degree of acceptance of other cultures in a multicultural educational environment. IFTE 2016 - 2nd International Forum on Teacher Education, 12, 103-108. https://doi.org/10.15405/epsbs.2016.07.17

Liu, M., \& Lin, T. B. (2011). The development of multicultural education in Taiwan: Overview and reflection. In C. A. Grant \& A. Portera (Eds.), Intercultural and multicultural education (pp. 157-76). Routledge.

Marshall, A. J. (2007). Vilfredo Pareto's sociology: A framework for political psychology. Ashgate Publishing.

Medkova, K. (2015). Intercultural competence development of Finnish higher education personnel. Lahti University of Applied Sciences.

Mostafazadeh, E., Keshtiaray, N., \& Ghulizadeh, A. (2015). Analysis of multi-cultural education concept in order to explain its components. Journal of Education \& Practice, 6(1), 1-12.

Nayar, S., \& Wright St.Clair, V. (2020). Multiple Cultures - One Process: Undertaking A Cross Cultural Grounded Theory Study. American Journal of Qualitative Research, 4(3), 131145. https://doi.org/10.29333/ajqr/9310

Napier, J. (2014). Multiculturalism and the dynamic tension between the one and the many. In L. Mwanri \& J. Waldenmaier (Eds.), Complex Migration of Global Citizens (pp. 4554). Inter-Disciplinary Press.

Nieto, S. (2017). Re-imagining multicultural education: New visions, new possibilities. $\begin{array}{llll}\text { Multicultural Education } & \text { Review, } & 9(1), & \text { 1-10. }\end{array}$ https://doi.org/10.1080/2005615X.2016.1276671

Rasool, S., \& Zhang, J. (2020). Bangladeshi, Indian, and Pakistani Parents' Perceptions of Their Children's Academic Achievement in Southwest Florida. American Journal of Qualitative Research, 4(3), 146-160. https://doi.org/10.29333/ajqr/9337

Sani, S. (2013). The role of intercultural pedagogy in the integration of immigrant students in Europe. Procedia - Social and Behavioral Sciences, 122, 484-490. https://doi.org/10.1016/j.sbspro.2014.01.1379

Shannon-Baker, P. (2018). A multicultural education praxis: Integrating past and present, living theories, and practice. International Journal of Multicultural Education, 20(1), 48-66. https://doi.org/10.18251/ijme.v20i1.1518

Sinyagin, N. Y., \& Rayfschnayder, T. Y. (2016). The policy of multicultural education in Russia: Focus on personal priorities. International Journal of Environmental \& Science Education, 11(18), 12613-12628.

Sleeter, C. E. (2018). Multicultural education past, present, and future: Struggles for dialog and power-sharing. International Journal of Multicultural Education, 20(1), 5-20. http://dx.doi.org/10.18251/ijme.v20i1.1663

Smolyaninova, O. G., \& Trufanov, D. O. (2018). "Double bottom" of Intercultural Competence: Evaluation by means of electronic educational platform of a Federal University. Journal 
of the Siberian Federal University. Series: Humanities, 11(10), 1673-1698. https://doi.org/10.17516/1997-1370-0327.

Toktamysov, S. Z., Vekilova, A. I. Q., Gasimzade, E. E., Kurilova, A. A., \& Mukhin, K. Y. (2019). Implementing the education of future entrepreneurs in developing countries: Agile integration of traditions and innovations. Journal of Entrepreneurship Education, 22(5), 1-13.

Toktamysov, S., Berestova, A., Israfilov, N., Truntsevsky, Y., \& Korzhuev, A. (2021). Empowerment or Limitation of the Teachers' Rights and Abilities in the Prevailing Digital Environment. International Journal of Emerging Technologies in Learning 16(2), 205-219.

UNESCO. (2006). UNESCO guidelines on intercultural education. UNESCO.

Wilder, L. K., Sanon, D., Carter, C., \& Lancellot, M. (2017). Narrative ethnographies of diverse faculty in higher education: "Moral" multiculturalism among competing worldviews. Journal of Ethnic \& Cultural Studies, 4(2), 1-12.

Yun, H., \& Zhang, J. (2017). The significance of the multicultural education based on the experiential learning of a local community. European Journal of Social Sciences Education \& Research, 4(4), 248-252. https://doi.org/10.26417/ejser.v10i2.p248-252

Yusupova, G. F., \& Markova, N. G. (2015). Educating young people in multicultural educational environment of higher education institution. International Journal of Environmental \& Science Education, 10(4), 561-570. https://doi.org/10.12973/ijese.2015.270a

Zilliacus, H., Holm, G., \& Sahlström, F. (2017). Taking steps towards institutionalising multicultural education-The national curriculum of Finland. Multicultural Education Review, 9(4), 231-248. https://doi.org/10.1080/2005615X.2017.1383810

\section{Notes on Contributors}

Endzhe Latypova is a PhD of Psychological Sciences, Associate Professor of the Center of Applied Psychology, Ethnopsychology and Intercultural Communication, Kazan Federal University, Kazan, Russia. Her research interests include multicultural education, international experience, multicultural environment, social interaction, national education, cultural diversity, dialogue of cultures, humanism. https://orcid.org/0000-0003-4668-3954

Vladimir Kozmenko is a Doctor of Historical Sciences, Professor of the Department of History of Russia, Peoples Friendship University of Russia (RUDN University), Moscow, Russia. His research interests include migrants, international experience, ethnocultural groups, ethnic studies, ethnicity, national education, cultural diversity. https://orcid.org/0000-00030702-9490

Saken Toktamysov is a $\mathrm{PhD}$ of Historical Sciences, Associate Professor of the Department of History of Russia, Peoples Friendship University of Russia (RUDN University), Moscow, Russia. His research interests include migrants, international experience, ethnocultural groups, ethnic studies, ethnicity, national education, cultural diversity. https://orcid.org/0000-0003-4284-9638 